\title{
ENVIRONMENTAL TAXES AND WAGE SETTING STRUCTURE
}

\author{
Juan Carlos Bárcena-Ruiz, María Begoña Garzón*
}

\begin{abstract}
:
The literature on the environment shows that imperfect competition in global markets creates a strategic interaction between governments that can lead to the inefficient distortion of environmental taxes. This literature does not consider that workers can set up different organizational structures to set wages. We assume that under decentralized wage setting there is an independent union in each firm while under centralized wage setting there is an industry-wide union that sets the wages of all firms. We show that under a decentralized structure governments choose environmental taxes closer to those which are socially efficient than those chosen under a centralized structure. However, environmental damage is greater in the former case.
\end{abstract}

Keywords: environmental taxes, unions' structure, international trade, oligopoly.

JEL Classification: J51, H23

\section{Introduction}

The link between environmental regulation, the labour market and international trade is widely acknowledged. In this context, environmental regulation by governments may reduce environmental pollution but it can also exacerbate the problem of unemployment. This is an important issue in policy debates on environmental regulation. However, theory alone yields an ambiguous prediction of the overall effects on employment of environmental regulation. ${ }^{1}$ In this regard, there are many papers arguing that if the revenue from environmental taxes is used to cut other distortionary taxes (such as labour taxes), it may improve both the environment and social welfare (see, for example, Goulder, 1995; Carraro et al., 1995; Bosquet, 2000; Chiroleu-Assouline and Fodha, 2006). In this sense, environmental regulations may provide a double dividend; this is referred to as "the double dividend hypothesis". Besides, the Porter effect points out that tough environmental regulation can trigger innovation that may increase a firm's competitiveness and that can outweigh the short-run private cost of this regulation (see Xepapadeas and De Zeew, 1999). ${ }^{2}$

* Departamento de Fundamentos del Análisis Económico I, Universidad del País Vasco. Avenida Lehendakari Aguirre, 83; 48015 Bilbao, Spain (juancarlos.barcena@ehu.es; mariabegona.garzon@ehu.es). Financial support from Ministerio de Ciencia y Tecnología and FEDER (SEJ2006-05596) and Departamento de Educación, Universidades e Investigación del Gobierno Vasco (IT-223-07) is gratefully acknowledged. The usual disclaimer applies.

1 See Wagner (2005) and Majocchi (1996) for an analysis of the issue that green taxes can be implemented without increasing unemployment.

2 This argument is supported by a large case of studies that prove that firms under strict environmental regulation are very successful (see Porter and van der Linde, 1995). 
On the other hand, international trade has been incorporating various aspects of environmental issues since 1970. The extent to which environmental problems might affect international trade, or vice versa, has been the subject of considerable debate over these years. Environmental issues can influence production costs, trade patterns, the location of industries, and, finally, gains from trade. Therefore, when analysing environmental issues is important to keep international trade in mind (see Jayadevappa and Chhatre, 2000). In relation to this issue, Smulders (2001) argues that the insights from the double dividend hypothesis can also be applied to the link between trade liberalization and environmental policy. He argues that the growing awareness of environmental problems might make it easier to set up environmental taxes that provide new sources of income for governments, thus allowing them to cut other distortionary taxes and tariffs. Then the question that arises is whether these new taxes are so powerful that they not only improve the environment but also provide the tools needed to reduce other problems such as unemployment or losses from restricted international trade.

The above discussion shows the relationship between international trade, environmental quality and the labour market. Although the number of papers analysing this issue is growing there is still much work to do. Many of these papers seek to determine whether or not there are double dividends. However, there are other related issues that remain to be studied such as whether environmental regulations set by governments under free trade are affected by the way in which workers are organized for wage bargaining. ${ }^{3}$ This is an important issue since the organizational structure of both domestic and foreign workers affects production costs and, thus, the market share of firms. As a result, it affects the environmental damage caused by firms and the environmental taxes set by governments. This means that governments should take into account the way in which workers are organized for wage bargaining when setting their environmental taxes. The objective of this paper is to analyse this issue. We do this by assuming that governments set taxes on environmental pollution but not on labour. In order to set this issue into context in the relevant literature we discuss first the literature on the environment under free trade and secondly the literature on wage bargaining.

The literature on the environment argues that free trade will lead governments to relax their environmental standards in order to give domestic firms a competitive advantage over foreign firms ${ }^{4}$ However, governments may also set stricter environmental standards

3 A related issue is analysed by Fredriksson and Gaston (1999), who study how demand for environmental regulation is influenced by institutional features of the labour market. They point out that from the perspective of policy-makers political support requires the reconciling of employment and environmental quality. The reasons behind union opposition to policies that threaten jobs are transparent, but union support for environmental regulation is ostensibly driven by the effects of pollution and environmental hazards on workers both on and off the job. Unions, however, may also support legislation that benefits their members by raising the cost of employing other production factors. Aronsson and Blomsquist (2003) carry out a related analysis. They study transboundary environmental problems in the context of an optimal tax problem with labor mobility; however, they do not consider that workers can set up different organizational structures to negotiate wages.

4 In this regard, Barrett (1994) shows that governments may have incentives to impose weak environmental standards (i.e. the marginal cost of abatement is less than the marginal damage from pollution) on industries that compete for business in imperfectly competitive international markets. Similarly, Ulph (1996) points out that there are incentives for producers to act strategically, e.g. through their investment in R\&D. 
to send unwanted pollution abroad. Kennedy (1994) examines these incentives taking production costs (and thus wage costs) as exogenously given. He shows that imperfect competition in global markets creates a strategic interaction between governments that can lead to the inefficient distortion of taxes on pollution. This distortion can be decomposed into a rent capture effect and a pollution-shifting effect. The rent capture effect lowers equilibrium taxes as each country attempts to capture foreign rents through net exports. The pollution-shifting effect raises equilibrium taxes as each country attempts to transfer production and its associated pollution to the other country. The net effect on symmetric equilibrium taxes is negative and therefore each government chooses lower than socially efficient environmental taxes. ${ }^{5}$ In this framework, the socially efficient environmental taxes are those that maximize the aggregated welfare of the two countries.

The literature on wage bargaining has focused mainly on two structures. ${ }^{6}$ In one, each firm negotiates with an independent union at firm level (decentralization) and in the other each firm bargains with an industry-wide union (centralization). ${ }^{7}$ Assuming simultaneous negotiations, Horn and Wolinsky (1988) and Davidson (1998) show that a centralized negotiation results in higher wages than a decentralized one since the bargaining strength of the workers is greater; therefore, workers prefer centralized bargaining while firms prefer decentralized bargaining. Bárcena-Ruiz (2003) extends the analysis to study the bargaining structure preferred by governments.

The literature on the environment does not consider that workers can adopt different organizational structures to set wages (see, for example, Barret, 1994; Kennedy, 1994; Ulph 1996). On the other hand, the literature on wage bargaining does not take into account that firms pollute the environment. In order to close this gap and take into account the relationship between environmental policy and the labour market, we analyse the choice of environmental taxes by governments when there is a unionized labour force in each country which can set up a centralized or a decentralized organizational structure to set wages. To study this question we consider a single market comprising two countries operating under free trade. There are two firms in each country and all firms produce a homogeneous goods whose production process produces results in pollution. The emission of pollutants by each firm affects only the country in which the firm is located; that is, we consider that environmental damage is local. There is unionized labour in each country that can adopt different organizational structures. Under decentralized wage setting there is an independent union at each firm that sets the wage, while under centralized wage setting there is an industry-wide union that sets the wages of both firms. In order to reduce firms' pollutant emissions, each government sets a positive environmental tax that maximizes the social welfare function of its country.

5 These effects are also studied by the literature on the environment that analyses how firms' choice of location is affected by the environmental taxes set by governments (see, for example, Markusen et al., 1993; Motta and Thisse, 1994; Rauscher, 1995; Markusen, 1997; Hoel, 1997; Bárcena-Ruiz and Garzón, 2003).

6 Empirical evidence shows that there are different negotiation structures in developed countries. In EU countries, in general, collective agreements are concluded between the relevant union and employers' association of an industry on a regional basis, in the U.S. wage bargaining is decentralized and Japanese labour unions are mostly enterprise-based organizations (see Hartog and Theeuwes, 1993).

7 See Dobson (1994), Malcomson (1987), Farber (1986), Oswald (1985) and McDonald and Solow (1981). 
In this framework, a strategic effect arises that influences both the rent capture effect and the pollution-shifting effect pointed out by Kennedy (1994). For a given environmental tax and wage setting structure in the foreign country, the unions of the domestic country set a lower wage under decentralization and therefore domestic firms produce more than under centralization. As a result, the decentralized structure makes for a weaker rent capture effect than the centralized one since it reduces the government's incentive to decrease the tax unilaterally to capture rents from abroad. On the other hand, for a given environmental tax and wage setting structure in the foreign country, if the wage setting structure is decentralized in the domestic country, more production and pollution is transferred there than under the centralized structure. As a result, the decentralized structure reinforces the pollution-shifting effect since it provides more incentives for each government to increase taxes and transfer pollution to the other country than the centralized structure. This means that the tax set by a government is greater under a decentralized structure than under a centralized one and, thus, nearer to the level which is socially efficient in the first case. Although governments set higher taxes under a decentralized structure, environmental damage is greater in this case. Moreover, for a given wage setting structure in one country, the environmental damage in that country is greater if there is a centralized structure rather than a decentralized one in the other country. This is because the centralized structure gives a strategic disadvantage to the firms located in the other country. Social welfare is greater under a decentralized structure than under a centralized one.

The remainder of the paper is organized as follows. Section 2 presents the model. Section 3 analyses the cases of centralized and decentralized bargaining. Section 4 compares the results obtained under the different wage bargaining structures and Section 5 draws conclusions.

\section{The Model}

We consider a single market comprising two countries, $A$ and $B$. In each country there are two firms, denoted by 1 and 2, and all firms use the same technology to produce a homogeneous good whose production process pollutes the environment. ${ }^{8}$ There is free trade, there are no transportation costs and there is no possibility of discriminating between consumers from different countries. Therefore, consumers in both countries can buy the product from either a domestic or a foreign firm.

The inverse demand function for the product in country $k$ is: $p=\alpha-2 y_{k}$, where $p$ is the price for the good in the world market and $y_{k}$ is the amount of the good sold in country $k, k=A, B$. Therefore, the world inverse demand function for the product is: $p=\alpha-\left(y_{A}+y_{B}\right)$, where $y_{A}+y_{B}=q_{A 1}+q_{A 2}+q_{B 1}+q_{B 2}$. Let $q_{k i}$ denote the amount of the good that firm $i$ located in country $k$, firm $k i$, sells in the single market $(k=A, B ; i=1,2)$. The consumer surplus in country $k$, denoted by $C S_{k}$, is: $C S_{k}=\left(y_{k}\right)^{2}, k=A, B$.

$8 \quad$ The results of the paper hold if we assume that there are $n(n>2)$ firms in each country. 
The only factor used in the production process is labour. Firm $k i$ hires $L_{k i}$ workers with a uniform wage rate $w_{k i}$. The technology used by the firms exhibits constant returns to scale such that: $q_{k i}=L_{k i}$ All workers are unionized and unions as well as firms are risk neutral. In order to determine the wage set at each firm, we consider the monopoly-union model, which assumes that the unions set the wage while the firms choose the employment level once the wage is set by unions (see Booth, 1995).

Unions can be centralized or decentralized. Under decentralized wage setting, there is an independent union at each firm that chooses the wage that maximizes its rents; therefore the utility function of the union at firm $k i$ is: $U_{k i}\left(w_{k i}, L_{k i}\right)=w_{k i} L_{k i}, k=A$, $B ; i=1,2$. In this case, the total utility obtained by the workers in country $k$ is given by: $U_{k}\left(w_{k 1}, w_{k 2}, L_{k 1}, L_{k 2}\right)=U_{k 1}\left(w_{k 1}, L_{k 1}\right)+U_{k 2}\left(w_{k 2}, L_{k 2}\right)$. Under centralized wage setting there is an industry-wide union that sets the wages of both firms. The utility function of the industry-wide union in country $k$ is: $U_{k}\left(w_{k 1}, w_{k 2}, L_{k 1}, L_{k 2}\right)=w_{k 1} L_{k 1}+w_{k 2} L_{k 2}, k=A, B$.

There is a pollutant associated with the production of the goods and each unit of the goods produced causes one unit of pollution. However, producers have technology available for abating this pollutant. If firm $k i$ chooses output level $q_{k i}$ and pollution abatement level $a_{k i}$, pollutant emissions by this firm are $q_{k i}-a_{k i}$. The total cost of pollution abatement at firm $k i$ is given by: $C A_{k i}=(d / 2) a_{k i}{ }^{2}$, where $d$ is a positive parameter $(k=A, B ; i=1,2)$.

Each government has the environmental tax per unit of pollutant emitted, $t_{k}$, as a decision variable. The firms located in country $k$ have to take into account the tax set in that country, $t_{k}$. Therefore, the profit of firm $k i$ is:

$$
\pi_{k i}=\left(\alpha-q_{A 1}-q_{A 2}-q_{B 1}-q_{B 2}-w_{k i}\right) q_{k i}-t_{k}\left(q_{k i}-a_{k i}\right)-(d / 2) a_{k i}^{2}, k=A, B ; i=1,2 .
$$

The total taxes collected by the government of country $k$ (government $k$ ) are: $T k=t_{k}\left(q_{k 1}-a_{k 1}+q_{k 2}-a_{k 2}\right)$. The producer surplus in country $k$, denoted by $P S_{k}$, is: $P S_{k}=$ $\pi_{k 1}+\pi_{k 2}, k=A, B$. In order to simplify the exposition of the results we assume that $d=1$, but the results of the paper can be shown to hold if $d$ is other than 1 .

We consider that the emission of pollutant by firm $k i$ affects only the country in which the firm is located; that is, we consider that the environmental damage is local. We use a quadratic functional form to measure the environmental damage generated in country $k$, denoted by $E D_{k}$, by the production process: ${ }^{9}$

$$
E D_{k}=(\gamma / 2)\left(q_{k 1}-a_{k 1}+q_{k 2}-a_{k 2}\right)^{2}, \gamma>0.3,
$$

where the positive parameter $\gamma$ measures the valuation of the environment by government $k .{ }^{10}$ This can be interpreted as willingness to pay to decrease environmental damage by one unit.

The social welfare considered by government $k$ comprises the consumer's surplus, $C S_{k}$, the producer's surplus, $P S_{k}$, the total taxes collected by government $k, T_{k}$, the rents

9 The literature on the environment usually assumes that environmental damage, which is exogenous for consumers and producers, is a convex function of the total pollution level See, for example, Falk and Mendelsohn (1993), van der Ploeg and Zeeuw (1992) and Ulph (1996).

10 We assume that $\gamma>0.3$ to assure that the environmental taxes set by the governments are positive independently of the structure adopted by workers in setting wages. 
obtained by the workers, $U_{k}$, and the environmental damage caused by the production process, $E D_{k}$. Specifically, we assume the following social welfare function:

$$
W_{k}=C S_{k}+P S_{k}+T_{k}+U_{k}-E D_{k}, k=A, B .
$$

This function includes the union rents as usual in literature (see, for example, Brander and Spencer, 1988; Mezzetti and Dinopoulos, 1991; Bughin and Vanini, 1995; Ulph, 1996; Naylor, 1998). Union rents are included as that part of the producer surplus which is absorbed by the unions.

Given that there are two countries and that workers can be organized in independent unions at firm level or in an industry-wide union in each country, there are three possible cases to be considered: decentralized wage setting in both countries (denoted by $D D$ ), centralized wage setting in both countries (denoted by $C C$ ), and centralized wage setting in one country and decentralized in the other (denoted by $C D$ and $D C$, respectively).

In order to analyse how the organizational structure adopted by workers in the two countries affects the environmental taxes chosen by the governments, we propose a three stage game with the following timing. In the first stage, the governments simultaneously set their environmental taxes. In the second stage, unions set wages simultaneously in the two countries. Finally, in the third stage, firms simultaneously choose their output and pollution abatement levels. We solve the game by backward induction from the last stage of the game to obtain a subgame perfect Nash Equilibrium.

\section{Centralized and Decentralized Wage Setting Structures}

First we solve the third stage of the game. The result of this stage of the game is identical independently of the wage setting structure considered. In the third stage, firm $k i$ chooses the output level $q_{k i}$ and the abatement level $a_{k i}$ that maximizes its profit, given by expression (1). Solving the first order conditions for profit maximization we obtain the equilibrium output, employment and abatement levels of the firms, as a function of environmental taxes and wage rates:

$q_{k i}=L_{k i}=(1 / 5)\left(\alpha-3 t_{k}+2 t_{l}-4 w_{k i}+w_{k j}+w_{l i}+w_{l j}\right), a_{k i}=t_{k}, k \neq l ; k, l=A, B ; i \neq j ; i, j=1,2$.

Expression (3) shows that the output level of firm ki decreases with the domestic tax and increases with the foreign tax. Besides, the output level of firm $k i$ decreases with the own wage and increases with the wage paid by the other firms. These results are due to the fact that domestic taxes and own wages increase the production cost of the firms and thus firms are less competitive in the product market. Finally $a_{k i}=t_{k}$ is the usual condition that the firm abates pollution to the point where marginal abatement cost equals the tax.

After solving the third stage of the game, we analyse first the case in which wage setting is decentralized in both countries.

\section{Decentralized Wage Setting in Both Countries}

In this case, there is an independent union at each firm in the two countries. In the second stage, unions set wages simultaneously in the two countries. The union at firm 
$k i$ sets the wage, $w_{k}$, that maximizes union rents, $U_{k i}$, taking into account the equilibrium of the third stage (given by expression (3)). Solving these problems we obtain:

$$
w_{k i}=(1 / 45)\left(9 \alpha-17 t_{k}+8 t\right), k \neq l ; k, l=A, B ; i=1,2 .
$$

It can be shown from (4) that a unilateral reduction in the domestic environmental tax raises the wage paid by domestic firms and reduces the wage paid by foreign firms, which reduces the competitive advantage of domestic firms.

Let $H_{1}=(\alpha /(6713+16994 \gamma))$. In the first stage, each government chooses the environmental tax that maximizes its social welfare given by (2). Solving these problems we obtain the following result.

Lemma 1. When wage setting is decentralized in both countries, in equilibrium:

$$
\begin{gathered}
q^{D D}=L^{D D}=1172 H_{1}(1+2 \gamma), \pi^{D D}=8\left(H_{1}\right)^{2}\left(195107+507476 \gamma+1030188 \gamma^{2}\right), \\
t^{D D}=a^{D D}=4 H_{1}(586 \gamma-153), w^{D D}=1465 H_{1}(1+2 \gamma), C S^{D D}=5494336\left(H_{1}\right)^{2}(1+2 \gamma)^{2}, \\
P S^{D D}=2 \pi^{D D}, E D^{D D}=6365312\left(H_{1}\right)^{2} \gamma, U^{D D}=3433960\left(H_{1}\right)^{2}(1+2 \gamma)^{2}, \\
T^{D D}=14272\left(H_{1}\right)^{2}(586 \gamma-153), W^{D D}=8\left(H_{1}\right)^{2}(1+2 \gamma)(1233299+3262262 \gamma) .
\end{gathered}
$$

Next we consider the case in which wage setting is centralized in both firms.

\section{Centralized Wage Setting in the Two Countries}

We now consider that there is an industry-wide union in each country. In the second stage, unions set wages simultaneously in the two countries. Union $k$ sets wages $w_{k 1}$ and $w_{k 2}$ that maximize union rents, $U_{k}$, taking into account the equilibrium of the third stage (given by expression (3)). Solving these problems we obtain:

$$
w_{k i}=(1 / 16)\left(4 \alpha-7 t_{k}+3 t_{l}\right), k \neq l ; k, l=A, B ; i=1,2 .
$$

Like expression (4), expression (5) shows that that the wage paid by domestic firms decreases with the domestic tax and increases with the foreign tax.

Let $H_{2}=(\alpha /(926+2323 \gamma))$. In the first stage, each government chooses the environmental tax that maximizes its social welfare given by (2). Solving these problems we obtain the following result.

Lemma 2. When wage setting is centralized in both countries, in equilibrium:

$$
\begin{gathered}
q^{C C}=L^{C C}=(303 / 2) H_{2}(1+2 \gamma), \pi^{C C}=(9 / 4)\left(H_{2}\right)^{2}\left(11769+29492 \gamma+61206 \gamma^{2}\right), \\
t^{C C}=a^{C C}=3 H_{2}(101 \gamma-28), w^{C C}=(505 / 2) H_{2}(1+2 \gamma), C S^{C C}=91809\left(H_{2}\right)^{2}(1+2 \gamma)^{2}, \\
P S^{C C}=2 \pi^{C C}, E D^{C C}=(221841 / 2)\left(H_{2}\right)^{2} \gamma, U^{C C}=(153015 / 2)\left(H_{2}\right)^{2}(1+2 \gamma)^{2}, \\
T^{C C}=1413\left(H_{2}\right)^{2}(101 \gamma-28), W^{C C}=(3 / 2)\left(H_{2}\right)^{2}(1+2 \gamma)(121142+316231 \gamma) .
\end{gathered}
$$

Next we consider the case in which workers adopt a centralized structure in one country and a decentralized one in the other. 


\section{Centralized Wage Setting in Country $k$ and Decentralized in Country I}

In the second stage, union $k$ sets wages $w_{k 1}$ and $w_{k 2}$ that maximize union rents, $U_{k}$, taking into account the equilibrium of the third stage (given by expression (3)). Union $l i$ sets wage $w_{l i}$ that maximizes union rents, $U_{l i}$, taking into account the equilibrium of the third stage (given by expression (3)). Solving these problems we obtain:

$$
w_{k i}=(1 / 38)\left(9 \alpha-17 t_{k}+8 t_{l}\right), w_{l i}=(1 / 19)\left(4 \alpha-7 t_{l}+3 t_{k}\right), k \neq l ; k, l=A, B ; i=1,2 .
$$

In the first stage, the governments simultaneously set their environmental taxes. Government $k$ chooses the tax that maximizes its social welfare function given by expression (2), taking into account the equilibrium obtained in stages two and three (expressions (3), (4), (5) and (6)). Solving these problems we obtain the following result.

Lemma 3. When wage setting is centralized in one country and decentralized in the other, in equilibrium:

$$
\begin{gathered}
q^{C D}=L^{C D}, q^{D C}=L^{D C}, \pi^{C D}, \pi^{D C}, t^{C D}=a^{C D}, t^{D C}=a^{D C}, w^{C D}, w^{D C}, C S^{C D}=C S^{D C} \\
P S^{C D}=2 \pi^{C D}, P S^{D C}=2 \pi^{D C}, E D^{C D}, E D^{D C}, U^{C D}, U^{D C}, T^{C D}, T^{D C}, W^{C D}, W^{D C},{ }^{11}
\end{gathered}
$$

Next we compare the results obtained in lemmas 1 to 3 to analyse how the organizational structure adopted by workers to set wages in the two countries affects the environmental taxes chosen by the governments.

\section{Comparison of Results}

Comparing lemmas 1 to 3 , we get the following results.

Lemma 4. In equilibrium: $w^{C C}>w^{C D}>w^{D C}>w^{D D} ; q^{D C}=L^{D C}>q^{D D}=L^{D D}>q^{C C}=$ $L^{C C}>q^{C D}=L^{C D} ; U^{C C}>\operatorname{máx}\left\{U^{C D}, U^{D C}\right\}>U^{D D}$, where $U^{C D}>U^{D C}$ if $\gamma>0.3382$; $C S^{D D}>C S^{C D}=C S^{D C}>C S^{C C} ; \pi^{D C}>\pi^{D D}>\pi^{C C}>\pi^{C D}$; and $P S^{D C}>P S^{D D}>P S^{C C}>P S^{C D}$.

This lemma shows that the wage paid in country $k$ depends mainly on the structure adopted by workers in setting wages in the two countries. The wage paid in a country is greater under centralization than under decentralization, independently of the structure adopted in the other country $\left(w^{C m}>w^{D m}, m=C, D\right)$, since workers are stronger in the first case (see Booth, 1995). Moreover, for a given structure in one country, the wage paid in that country is greater if the structure adopted in the other country is centralized rather than decentralized $\left(w^{m C}>w^{m D}, m=C, D\right)$.

The production of the firms (and, thus, the employees hired) depends mainly on the wage setting structure. When the wage setting structure is decentralized in country $k$ and centralized in country $l$, the firms located in country $k$ (country $l$ ) produce a higher (lower) output and hire more (less) employees. As the wage paid in country $k$ is lower than in country $l$, the firms in country $k$ gain market share at the expense of those in

11 This values are relegated to the appendix. 
the other country. The intermediate production and employment level is obtained when workers in the two countries adopt the same structure in setting wages. However, as the wage is greater under a centralized structure, the output of the firms is greater under a decentralized one.

The total output of industry is higher (lower) when the wage setting structure is decentralized (centralized) in both countries. Given that the consumer surplus increases with the output of industry, the highest (lowest) consumer surplus is obtained when the wage setting structure is decentralized (centralized) in both countries. The intermediate consumer surplus is obtained when the wage setting structure is centralized in one country and decentralized in the other since, in this case, the total output of industry takes an intermediate value.

Given that wage has a greater effect than employment level on the utility of unions, the highest (lowest) unions utility is obtained when the wage setting structure is centralized (decentralized) in both countries.

Finally, the wages paid by the firms determine their market shares, which in turn determine their profits. It must be noted that although firms must pay a tax and abate emissions, the result obtained when comparing profits is due mainly to the way in which workers are organized in setting wages. On the other hand, given that $\left(P S^{m n}=2 \pi^{m n},(m, n=C, D)\right.$, we obtain that $P S^{D C}>P S^{D D}>P S^{C C}>P S^{C D}$.

From lemmas 1 to 4 we obtain the following result.

Proposition 1. In equilibrium: $t^{D C}>t^{D D}>t^{C C}>t^{C D}, T^{D C}>T^{D D}>T^{C C}>T^{C D}, E D^{D C}>$ $E D^{D D}>E D^{C C}>E D^{C D}, W^{D C}>W^{D D}>W^{C C}>W^{C D}$ and $2 W^{D D}>W^{C D}+W^{D C}>2 W^{C C}$.

For a given wage setting structure, we distinguish two strategic effects that explain the choice of environmental taxes by governments: the rent capture effect and the pollution-shifting effect. The rent capture effect encourages each government unilaterally to reduce the environmental tax that domestic firms have to pay to give them a competitive advantage over foreign firms. This reduction in the domestic tax raises the net exports of domestic firms (since their costs decrease) and so permits the capture of rents from foreigners. This effect tends to reduce the equilibrium taxes below their efficient levels. The pollution-shifting effect works in the opposite direction. Each government has the incentive unilaterally to increase the tax to transfer production and its associated pollution to the other country. It can be shown that for a given wage setting structure the rent capture effect is stronger than the pollutionshifting effect and, thus, taxes are lower than is socially efficient.

When the wage setting structure may be centralized or decentralized, an additional strategic effect arises that influences the other two effects. On the one hand, for a given wage setting structure in the domestic country the wage paid and the output level of the firms in that country are greater if the structure adopted in the foreign country is centralized rather than decentralized $\left(\mathrm{w}^{\mathrm{mC}}>w^{m D}, q^{m C}>q^{m D}, m=C, D\right)$. Thus, a centralized structure in the foreign country raises the net exports of domestic firms and so permits the capture of greater rents from foreigners than a decentralized one. Therefore, the centralized structure makes the rent capture effect in the domestic country weaker than in the decentralized one, since it reduces each government's incentive to decrease the tax unilaterally to capture rents from foreigners. On the other hand, for a given wage setting 
structure in the domestic country, more production and pollution is transferred to the domestic country if the wage setting structure in the foreign country is centralized rather than decentralized. As a result, the centralized structure in the foreign country reinforces the pollution-shifting effect in the domestic country since the domestic government has more incentive to increase taxes and transfer pollution to the other country than under the decentralized structure. This means that the taxes set by each government are greater if the structure adopted in the foreign country is centralized rather than decentralized $\left(t^{m C}>t^{m D}, m=C, D\right)$. Moreover, if the wage setting structure is the same in both countries, the taxes set under decentralization are greater than under centralization $\left(t^{D D}>t^{C C}\right)$ : as $q^{D D}$ is greater than $q^{C C}$ the decentralized structure weakens the rent capture effect and reinforces the pollution-shifting effect. As a result, $t^{D C}>t^{D D}>t^{C C}>t^{C D}$.

Given that $t^{D C}>t^{D D}>t^{C C}>t^{C D}$ the abatement level of the firms is greater under decentralization than under centralization. However, the higher output of the firms under a decentralized structure $\left(q^{D C}>q^{D D}>q^{C C}>q^{C D}\right)$ implies greater emissions. Therefore, as both the emissions of the firms and environmental taxes are greater under decentralization than under centralization, the total taxes collected by the governments are also greater: $T^{D C}>T^{D D}>T^{C C}>T^{C D}$.

Given that environmental damage in one country depends positively on the pollution caused by the firms and that the emissions level is greater under a decentralized wage setting structure than under a centralized one, we can conclude that environmental damage is greater under a decentralized structure. Moreover, for a given wage setting structure in one country, the environmental damage in that country is greater if there is a centralized structure rather than a decentralized one in the other country.

We have seen that the environmental tax in a country is greater under a decentralized structure than under a centralized one, which means that the tax is nearer to socially efficient levels in the former case. This implies that in that country social welfare is greater under a decentralized structure than under a centralized one. Moreover, the social welfare obtained in that country is greater if there is a centralized structure in the other country than if there is a decentralized one. Finally, the highest (lowest) aggregate social welfare in the two countries is obtained when both have a decentralized (centralized) wage setting structure.

\section{Conclusion}

This paper analyses the link between international trade, environmental quality and the labour market. One important issue that remains to be studied in this topic is whether the environmental regulations set by governments under free trade are affected by the way in which workers are organized for wage bargaining. This is an important issue since the organizational structure of both domestic and foreign workers affects production costs and, thus, the market share of firms. As a result, it alters the environmental damage caused by firms and the environmental taxes set by governments. This means that governments should take into account the way in which workers are organized for wage bargaining when setting their environmental taxes.

The literature on the environment shows that imperfect competition in free trading economies creates a strategic interaction between governments when they choose their environmental taxes to reduce pollution. However, this literature considers that the 
wage is exogenously given and, therefore, does not consider the idea that workers may set up different organizational structures to set wages. In order to close this gap and take into account the relationship between environmental policy, international trade and the labour market, this paper analyses the environmental taxes chosen by governments when unionized labour can set up different structures for wage bargaining.

We show that the environmental taxes chosen by governments under decentralization are greater than under centralization. On the one hand, for a given environmental tax and wage setting structure in the foreign country, the unions of the domestic country set a lower wage under decentralization and domestic firms produce more than under centralization. This reduces the incentive that a government has to decrease the tax unilaterally to increase domestic firms' market share from foreigners. On the other hand, for a given environmental tax and wage setting structure in the foreign country, if the wage setting structure of the domestic country is decentralized, more production and pollution is transferred to that country than under the centralized structure. Therefore, the decentralized structure provides more incentives for each government to increase taxes and transfer pollution to the other country than the centralized structure. As a result, under decentralized wage setting in a country, its environmental tax is nearer to socially efficient levels. This means that social welfare is greater under a decentralized structure than under a centralized one, although the environmental damage is also greater.

One issue that is not considered in the paper is that the way in which workers are organized for wage bargaining could affect the form in which governments use the income obtained from environmental taxes to reduce taxes on employment. Besides, it should be interesting to test the theoretical predictions raised in the paper. However, it should be complex since there are factors not considered in the paper (as, for example, the fact that some firms are located in countries with no wage negotiations) that can influence the results. This issues lie outside the goals outlined in the paper and are left for future work.

\section{References}

Aronsson, T., Blomquist, S. (2003), "Optimal Taxation, Global Externalities and Labor Mobility." Journal of Public Economics, 87, pp. 2749-2764.

Bárcena-Ruiz, J. C., Garzón, M. B. (2003), "Strategic Environmental Standards, Wage Incomes and the Location of Polluting Firms." Environmental and Resource Economics 24, pp. 121-139.

Bárcena-Ruiz, J. C. (2003), "Politically Preferred Wage Bargaining Structures." European Journal of Political Economy, 19, pp. 341-353.

Barrett, S. (1994), "Strategic Environmental Policy and International Trade." Journal of Public Economics, 54, pp. 325-338.

Bosquet, B. (2000), "Environmental Tax Reform: Does it Work? A Survey of the Empirical Evidence." Ecological Economics 34, pp. 19-32.

Brander, J., Spencer, B. (1988), "Unionized Oligopoly and International Trade Policy." Journal of International Economics, 24, pp. 217-234.

Booth, A. (1995), The Economics of the Trade Union. Cambridge; New York: Cambridge University Press.

Bughin, J., Vanini S. (1995), "Strategic Direct Investment under Unionized Oligopoly." International Journal of Industrial Organization, 13, pp. 127-145.

Carraro, C., Galeotti, M., Gallo, M. (1995), "Environmental Taxation and Unemployment: some Evidence on the "Double Dividend Hypothesis" in Europe." Journal of Public Economics, 62, pp. 141-181. 
Chiroleu-Assouline, M., Fodha, M. (2006), "Double Dividend Hypothesis, Golden Rule and Welfare Distribution." Journal of Environmental Economics and Management, 51, pp. 323-335.

Davidson, C. (1988), "Multiunit Bargaining in Oligopolistic Industries." Journal of Labor Economics, 6, pp. 397-422.

Dobson, P. W. (1994), "Multifirm Unions and the Incentive to Adopt Pattern Bargaining in Oligopoly." European Economic Review, 38, pp. 87-100.

Falk, I., Mendelson, R. (1993), "The Economics of Controlling Stock Pollutants: An Efficient Strategy for Greenhouse Gases." Journal of Environmental Economics and Management, 25, pp. 75-88.

Farber, H. (1996), "The Analysis of Union Behavior," in Ashenfelter, O., Layard, R., eds., Handbook of Labor Economics. Vol. II, Elsevier Science Publishers.

Fredriksson, P. G., Gaston, N. (1999), "The "Greening" of Trade Unions and the Demand for Eco-Taxes." European Journal of Political Economy, 15, pp. 663-686.

Goulder, L. H. (1995), "Environmental Taxation and the "Double Dividend": a Reader's Guide." International Taxation and Public Finance, 2, pp. 157-183.

Hartog J., Theeuwes, J. (1993), Labour Markets Contracts and Institutions. Amsterdam: North Holland.

Hoel, M. (1997), "Environmental Policy with Endogenous Plant Locations." Scandinavian Journal of Economics, 99, pp. 241-259.

Horn, H., Wolinsky, A. (1988), "Bilateral Monopolies and Incentives for Merger." Rand Journal of Economics, 19, pp. 408-419.

Jayadevappa, R., Chhatre, S. (2000), International Trade and Environmental Quality. A Survey, Ecological Economics, 32, pp. 175-194.

Kennedy, P. (1994), "Equilibrium Pollution Taxes in Open Economies with Imperfect Competition." Journal of Environmental Economics and Management, 27, pp. 49-63.

Majocchi, A. (1996), "Green Fiscal Reform and Employment: A Survey." Environmental and Resource Economics, 8, pp. 375-397.

Malcomson, J. (1987), "Trade Union Labor Contracts: An Introduction." European Economic Review, 31, pp. 139-148.

Markusen, J. R., Morey, E. R., Olewiler, N. (1993), “Environmental Policy when Market Structure and Plant Locations are Endogenous." Journal of Environmental Economics and Management, 24, pp. 69-86.

Markusen, J. R. (1997), "Costly Pollution Abatement, Competitiveness and Plant Location Decisions." Resource and Energy Economics, 19, pp. 299-320.

Mezzettti, C., Dinopoulos, E. (1991), "Domestic Unionization and Import Competition." Journal of International Economics, 31, pp. 79-100.

McDonald, I., Solow, R. (1981), "Wage Bargaining and Employment." American Economic Review, 71, pp. 896-908.

Motta, M., Thisse, J. F. (1994), "Does Environmental Dumping Lead to Delocation?" European Economic Review, 38, pp. 563-576.

Naylor, R. (1998), "International Trade and Economic Integration when Labour Markets are Generally Unionised." European Economic Review, 42, pp.1251-1267.

Oswald, A. J. (1985), "The Economic Theory of Trade Unions: an Introductory Survey." Scandinavian Journal of Economics, 87, pp. 160-183.

Porter, M., van der Linde, C. (1995), "Toward a New Conception of the Environment-Competitiveness Relationship." Journal of Economic Perspectives, 9, pp. 97-118.

Rauscher, M. (1995), "Environmental Regulation and the Location of Polluting Industries." International Taxation and Public Finance, 2, pp. 229-244.

Smulders, S. (2001), "Environmental Taxation in Open Economies: Trade Policy Distortions and the Double Dividend," in Schulze, G., Ursprung, H., eds., International Environmental Economics: A Survey of the Issues. Oxford: Oxford University Press.

Ulph, A. (1996), "Environmental Policy and International Trade when Governments and Producers Act Strategically." Journal of Environmental Economics and Management, 30, pp. 265-281. 
van der Ploeg, F., de Zeeuw A. J. (1992), "International Aspects of Pollution Control." Environmental and Resource Economics, 2, pp. 117-139.

Wagner, T. (2005), "Environmental Policy and the Equilibrium Rate of Unemployment." Journal of Environmental Economics and Management, 49, pp. 132-156.

Xepapadeas, A., de Zeeuw A. J. (1999), "Environmental Policy and Competitiveness: The Porter Hypothesis and the Composition of Capital." Journal of Environmental Economics and Management, 37, pp. 165-182.

\section{Appendix}

Let $\mathrm{H}^{3}=(\alpha /(4542641+4 \gamma(6496756+9159687))$. When the wage setting structure is centralized in one country and decentralized in the other, in equilibrium:

$$
\begin{aligned}
& t^{C D}=a^{C D}=3 H_{3}(4 \gamma(5882+385359 \gamma)-137323), w^{C D}=5 H_{3}\left(234763+1240244 \gamma+1541436 \gamma^{2}\right), \\
& t^{D C}=a^{D C}=4 H_{3}(4 \gamma(23149+326073 \gamma)-102571), w^{D C}=15 H_{3}\left(69497+356376 \gamma+434764 \gamma^{2}\right), \\
& q^{C D}=L^{C D}=3 H_{3}\left(234763+1240244 \gamma+1541436 \gamma^{2}\right), \\
& q^{D C}=L^{D C}=12 H_{3}\left(69497+356376 \gamma+434764 \gamma^{2}\right), \\
& \pi^{C D}=9\left(H_{3}\right)^{2}\left(129084938667+1158191737600 \gamma+4101103252872 \gamma^{2}+\right.
\end{aligned}
$$$$
\left.7719560813952 \gamma^{3}+7128074826288 \gamma^{4}\right) \text {, }
$$$$
\pi^{D C}=8\left(H_{3}\right)^{2}\left(97457804203+872618934760 \gamma+3114810884008 \gamma^{2}+\right.
$$$$
\left.5819364833568 \gamma^{3}+5103532863792 \gamma^{4}\right),
$$$$
C S^{C D}=C S^{D C}=9\left(H_{3}\right)^{2}(1+2 \gamma)^{2}(512751+1640246 \gamma)^{2}, P S^{C D}=2 \pi^{C D},
$$$$
E D^{C D}=72\left(H_{3}\right)^{2} \gamma(186043+608358 \gamma)^{2}, E D^{D C}=128\left(H_{3}\right)^{2} \gamma(155531+488266 \gamma)^{2} \text {, }
$$$$
U^{C D}=30\left(H_{3}\right)^{2}(1+2 \gamma)^{2}(234763+770718 \gamma)^{2},
$$$$
U^{D C}=360\left(H_{3}\right)^{2}(1+2 \gamma)^{2}(69497+217382 \gamma)^{2},
$$$$
T^{C D}=36\left(H_{3}\right)^{2}(186043+608358 \gamma)\left(-137323+23528 \gamma+1541436 \gamma^{2}\right) \text {, }
$$$$
T^{D C}=64\left(H_{3}\right)^{2}(155531+488266 \gamma)\left(-102571+92596 \gamma+1304292 \gamma^{2}\right) \text {, }
$$$$
W^{C D}=6\left(H_{3}\right)^{2}(1+2 \gamma)(710278223513+82 \gamma(78519879385+
$$

$6 \gamma(39389980133+39344185562 \gamma))$,

$W^{D C}=\left(H_{3}\right)^{2}(1+2 \gamma)(4643296949633+2 \gamma(20865656382475+$

$9158 \gamma(6798390881+6730680294 \gamma))$. 